\title{
An improved pollen number counting method using a cell counter and mesh columns
}

\author{
Hiroyuki Kakui ${ }^{1 *} \mathbb{0}$, Eriko Tsurisaki ${ }^{2}$, Hidenori Sassa $^{3}$ and Yoshinari Moriguchi ${ }^{1}$
}

\begin{abstract}
Background: The determination of pollen number is important in evolutionary, agricultural, and medical studies. Tree species of the Cupressaceae family cause serious pollinosis worldwide. Although Japanese cedar (Cryptomeria japonica) is the most important forestry species in Japan, it is also the biggest cause of pollinosis in the country. Japanese cedar trees have been selected for growth speed and superior morphological traits and then cloned. These clones may vary in their pollen production, but there has been little research on how many pollen grains are produced by a single male strobilus (flower). A recently reported method for counting pollen number with a cell counter was applicable to Arabidopsis species and wheat, but was not suitable for Japanese cedar because the strobilus does not open with heating (e.g. $60^{\circ} \mathrm{C}$, overnight).

Results: Here, we report an improved pollen counting method for Japanese cedar using a precise and rapid cell counter in combination with home-made mesh columns. The male strobilus was gently crushed using a pestle. Large and small debris were then removed using 100- and 20- $\mu \mathrm{m}$ mesh columns, respectively. We successfully detected pollen sizes and numbers that differed between two clones using this method.

Conclusions: This improved method is not only suitable for counting pollen from Japanese cedar, but could also be applied to other species of the Cupressaceae family with hard scale tissue covering the pollen. Moreover, this method could be applied to a broader range of plant species, such as wheat, because there is no need to wait for anthesis and debris can be removed efficiently.
\end{abstract}

Keywords: Pollen number, Pollen size, CASY cell counter, Japanese cedar (Cryptomeria japonica)

\section{Background}

The determination of pollen grain number is important in evolutionary, agricultural, and medical studies. From an evolutionary perspective, selfing plant species tend to produce lower pollen numbers than closely related outcrossing plant species [1-5]. The reduced pollen number in selfing plants is thought to decrease the cost of pollen production. From an agricultural perspective, domesticated species such as rice tend to have low pollen numbers [6]; however, the production of large numbers of pollen grains is one of the desired traits in hybrid wheat

*Correspondence: kakui@agr.niigata-u.ac.jp

${ }^{1}$ Graduate School of Science and Technology, Niigata University, Niigata, Niigata 950-2181, Japan

Full list of author information is available at the end of the article breeding [7]. A high pollen number is also a desired trait for crops that require artificial pollination because artificial pollination require a lot of pollen $[8,9]$. From a medical perspective, pollen is relevant because it can lead to an allergic reaction called pollinosis $[10,11]$.

The recent development of next-generation sequencing techniques has enabled the genomic sequences of almost 600 plant species to be determined [12]. These sequenced genomes include those of plant species that have huge genome sizes, such as sugar pine $(27.6 \mathrm{~GB})$ or wheat (16 GB) [13, 14]. Combined analyses of sequence and phenotype data is a powerful tool for the identification of new genes. We recently identified a gene controlling pollen number using a genome-wide association study in Arabidopsis thaliana [5]. To estimate the

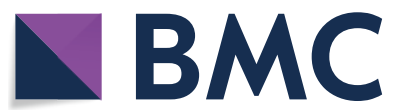

(c) The Author(s) 2020. This article is licensed under a Creative Commons Attribution 4.0 International License, which permits use, sharing, adaptation, distribution and reproduction in any medium or format, as long as you give appropriate credit to the original author(s) and the source, provide a link to the Creative Commons licence, and indicate if changes were made. The images or other third party material in this article are included in the article's Creative Commons licence, unless indicated otherwise in a credit line to the material. If material is not included in the article's Creative Commons licence and your intended use is not permitted by statutory regulation or exceeds the permitted use, you will need to obtain permission directly from the copyright holder. To view a copy of this licence, visit http://creativeco mmons.org/licenses/by/4.0/. The Creative Commons Public Domain Dedication waiver (http://creativecommons.org/publicdomain/ zero/1.0/) applies to the data made available in this article, unless otherwise stated in a credit line to the data. 
pollen number from $A$. thaliana accessions, we developed a high-throughput method to count pollen grains efficiently [15]. Pollen numbers showed large variation within individuals and between species; therefore, the phenotyping step should be optimized based on the plant species and pollen number variation determined in a preliminary experiment.

The Cupressaceae family is conifer species with a world-wide distribution and it contains species causing serious pollinosis such as cypress (Cupressus species, Chamaecyparis obtusa), Japanese cedar (Cryptomeria japonica), and mountain cedar (Juniperus ashei) [16]. Japanese cedar is an evergreen tree and is the most important forestry species in Japan because it has excellent properties for use in Japanese architecture [17]. However, the pollen of Japanese cedar is the most serious allergen in Japan. Although the pollen grain number of Japanese cedar has been reported previously $[18,19]$, sample numbers were limited. Traditionally, the number of pollen grains has been counted using a hemocytometer under a microscope [20-22], but this method is time-consuming and laborious. Recently, efficient pollen counting methods using cell counter were developed [CASY cell counter (OMNI Life Science, Germany [15]) or Ampha Z32 (Amphasys, Switzerland [23, 24])]. Anthers from these plants were forcibly opened by heating $\left(60^{\circ} \mathrm{C}\right.$, overnight) from $A$. thaliana and wheat [15]. To count pollen grains of Japanese cedar using a cell counter, we attempted to apply the same protocol; however, the male strobilus (flower) of Japanese cedar consists of a hard scale structure and it did not open with heating. Here, we report an improved pollen counting protocol using a cell counter and home-made mesh columns. We confirmed that Japanese cedar pollen can be counted efficiently using this method.

\section{Methods \\ Plant materials}

Trees of Japanese cedar (Cryptomeria japonica) were grown in the Niigata prefectural forest research institute. Three clones, 'Iwafune-9', 'Iwafune-15', and 'Nishikanbara-1' were used. Male strobili were collected in February 2020. Pollen grains are already matured during this period [25].

\section{Preparation of home-made mesh columns}

To remove large and small debris, two types of polyester mesh [20- $\mu$ m opening size (MEDIFAB 07-20/13, Sefar AG, Switzerland) and $100-\mu \mathrm{m}$ opening size (PETEX PET105, Sefar AG)] were used. The concept of using mesh columns was derived from a protein experimental protocol [26]. The bottom of a $0.6-\mathrm{mL}$ sample tube was removed around the $100-\mu \mathrm{L}$ line using scissors and bound with the polyester mesh by heating (for details see Fig. 1). The pieces of mesh were $1 \times 1 \mathrm{~cm}$ (Fig. 1).

\section{Preparation of pollen suspension}

A flowchart of the pollen suspension preparation method is provided in Fig. 2. The male strobilus was gently crushed using a pestle in a $1.5-\mathrm{mL}$ tube and $250 \mu \mathrm{L}$ of distilled water (DW) was added to the $1.5-\mathrm{mL}$ tube (Figs. 3a-d). The pollen-containing suspension was moved to a new 1.5-mL tube. To collect almost all of the pollen, an additional $250 \mu \mathrm{L}$ of DW was added to the first tube and remaining pollen was suspended. This suspension was then added to the first pollen suspension for a total volume of $500 \mu \mathrm{L}$. The suspension was transferred to a $100-\mu \mathrm{m}$ mesh column and centrifuged at $2000 \mathrm{~g}$ for $5 \mathrm{~s}$. The column retaining the large male strobilus tissues was discarded and the flowthrough was transferred to a $20-\mu \mathrm{m}$ mesh column. This suspension was centrifuged at $2000 \mathrm{~g}$ for $1 \mathrm{~min}$. Particles $>20 \mu \mathrm{m}$ that were trapped by the mesh were suspended with $500 \mu \mathrm{L}$ of DW and transferred to a new $1.5-\mathrm{mL}$ tube. The $20-\mu \mathrm{m}$ mesh column was washed with another $500 \mu \mathrm{L}$ of DW to collect almost all of the remaining particles and transferred to the 1.5$\mathrm{mL}$ tube for a total volume of $1 \mathrm{~mL}$.

\section{Pollen counting using a CASY cell counter}

The cell counter (CASY cell counter) parameters were set as described in Table 1. We chose the size range from 27.75 to $45 \mu \mathrm{m}$ as pollen particle because this range covered pollen peak from all samples without contamination from small/large particles. A 200- $\mu \mathrm{L}$ pollen suspension was mixed with $10 \mathrm{~mL}$ of CASYton (OMNI Life Science). Particle numbers were counted using a cell counter by sampling $400 \mu \mathrm{L}$ three times. Viable cells were calculated as the total pollen number per strobilus using the following equation:

(See figure on next page.)

Fig. 1 Home-made mesh columns. a Left to right: 0.6-mL tube, 0.6-mL tube with cut tip, mesh attached to 0.6-mL tube (column), and polyester meshes (20- $\mu \mathrm{m}$ and $100-\mu \mathrm{m}$ opening sizes). $\mathbf{b}-\mathbf{g}$ Column preparation. The bottom of a $0.6-\mathrm{mL}$ sample tube was removed around the $100-\mu \mathrm{L}$ line using scissors (b and $\mathbf{c}$ ). The cut surface was heated using a cigarette lighter ( $\mathbf{d}$ and $\mathbf{e}$ ). The heated surface was bound with $1 \times 1 \mathrm{~cm}$ pieces of polyester mesh ( $\mathbf{f}$ and $\mathbf{g}$ ). The background squares were $1 \times 1 \mathrm{~cm}$ 

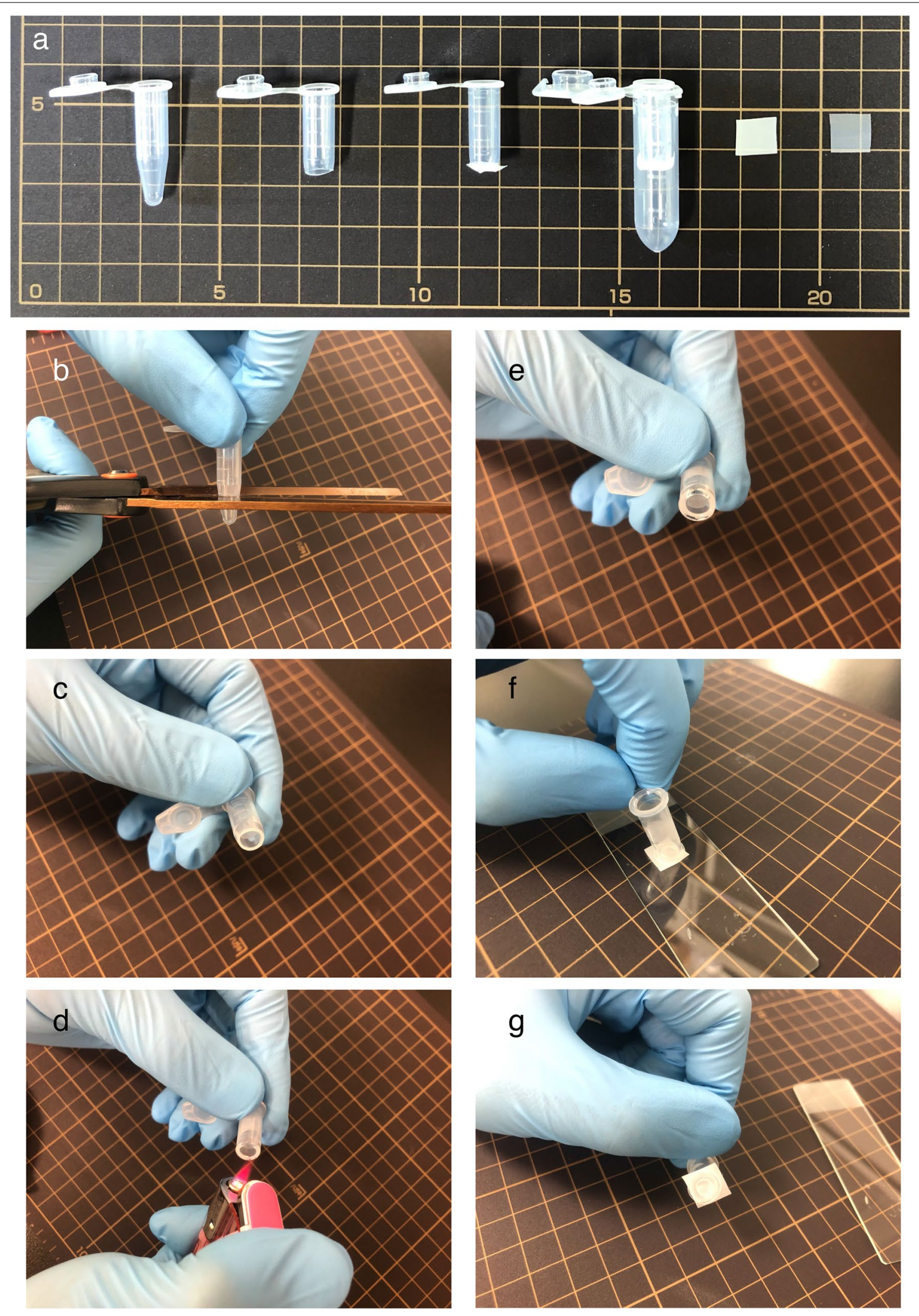
Kaki et al. Plant Methods

(2020) $16: 124$

Page 4 of 13

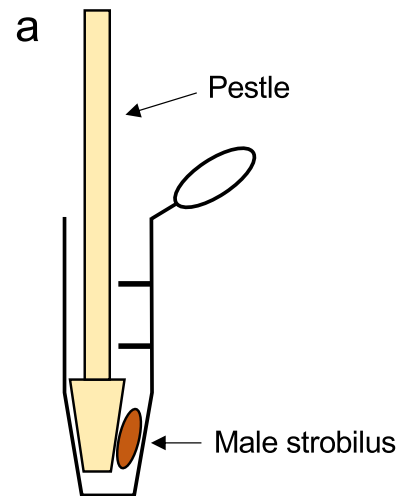

Push male strobilus gently Suspend with DW $(250 \mu \mathrm{L} \times 2)$

b

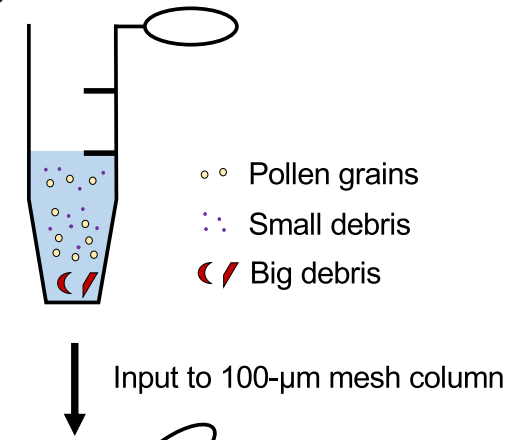

C
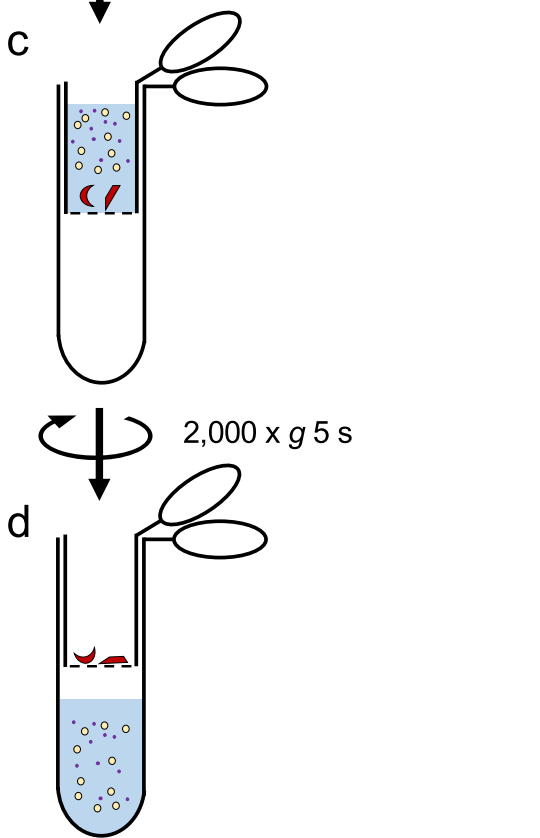

Discard 100- $\mu \mathrm{m}$ column Input to 20- $\mu \mathrm{m}$ mesh column
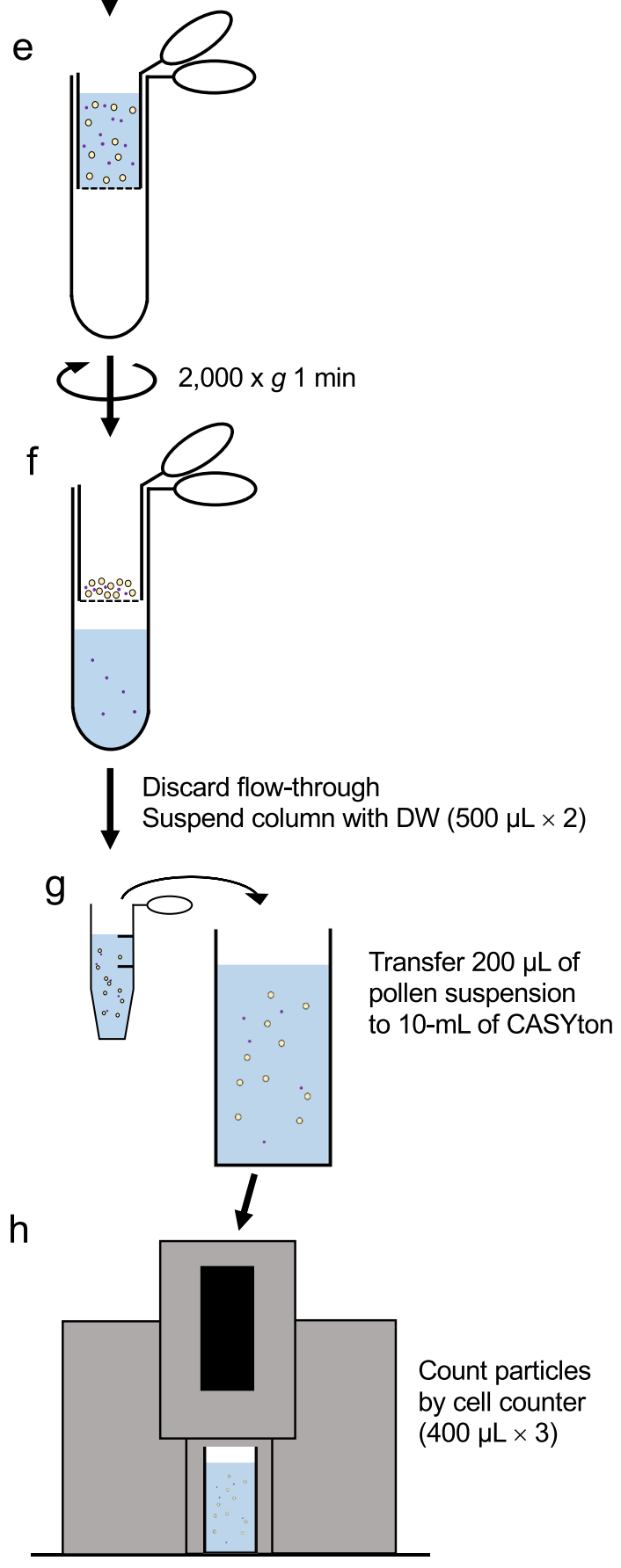

Fig. 2 Flowchart of the pollen grain counting technique. Outline of the protocol and the corresponding procedure steps. a Male strobilus is crushed gently in a 1.5 -mL tube and suspended by DW $(250 \mu \mathrm{L} \times 2)$. $\mathbf{b}-\mathbf{d}$ Pollen suspension is transferred to $100-\mu \mathrm{m}$ mesh column and centrifuged to remove bigger debris. $\mathbf{e}, \mathbf{f}$ The flowthrough is transferred to a $20-\mu \mathrm{m}$ mesh column and centrifuged to remove small debris. $\mathbf{g}$ Pollen-containing particles are mixed with water again $(500 \mu \mathrm{L} \times 2)$. Part of pollen suspension ( $200 \mu \mathrm{L}$ of $1 \mathrm{ml})$ is mixed with $10 \mathrm{~mL}$ of CASYton. $\mathbf{h}$ Particle numbers are counted by a cell counter 

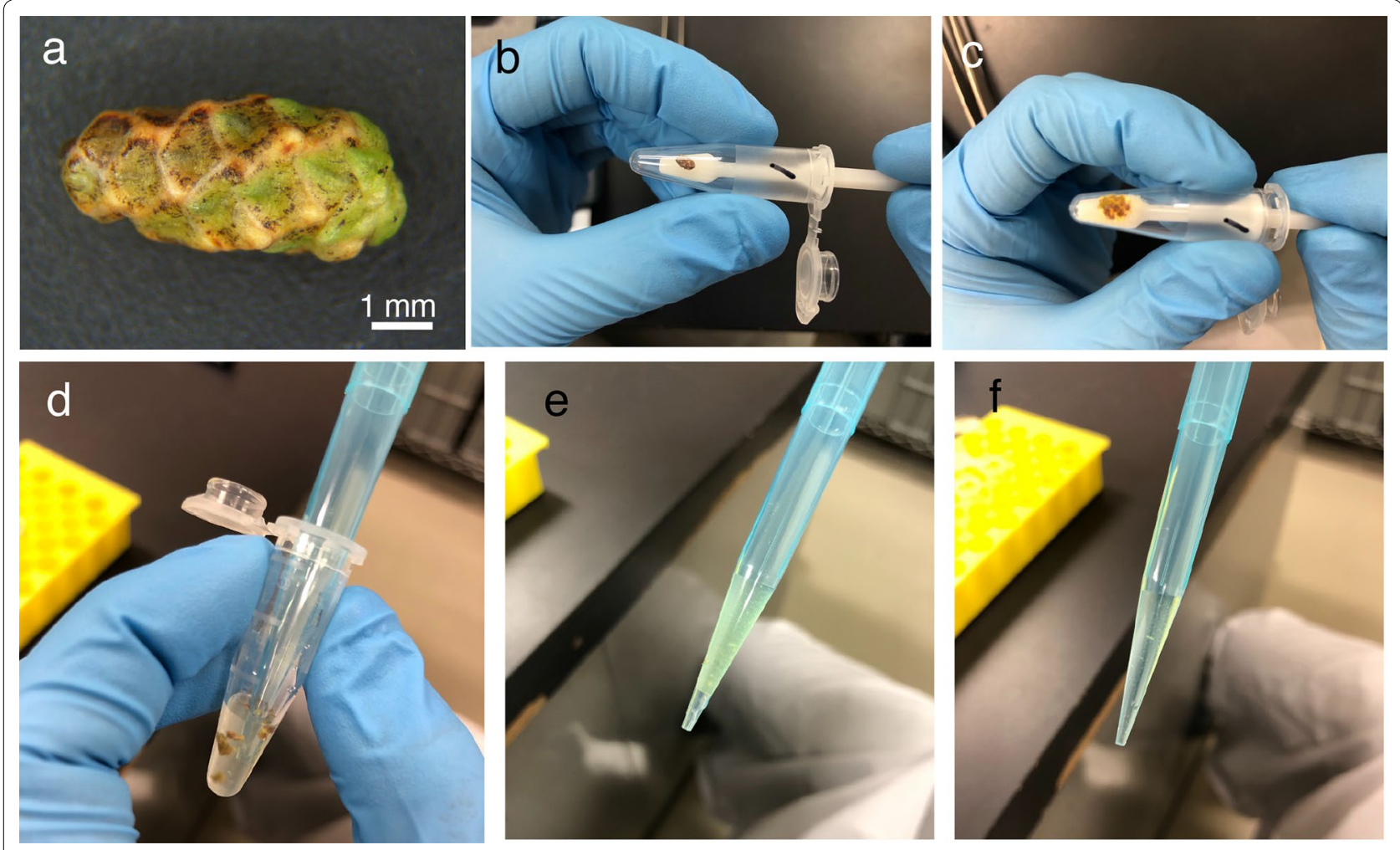

Fig. 3 Crushing and collecting pollen-containing liquid from male strobilus. a Male strobilus of Japanese cedar. Pollen grains were covered by a hard scale structure. Bar indicates $1 \mathrm{~mm}$. b, c Male strobilus crushed by a pestle. $\mathbf{d}$-f Pollen-containing suspension. Pollen-containing particles were collected from two suspensions (e and $\mathbf{f}$ )

\section{Table 1 Parameter for counting pollen number \\ of Japanese cedar}

\section{Capillary size}

Size scale

Range: debris

Range: dead cells

Range: viable cells

Sample volume

\begin{tabular}{l}
$150 \mu \mathrm{m}$ \\
$50 \mu \mathrm{m}$ \\
$<20 \mu \mathrm{m}$ \\
$20-27.74 \mu \mathrm{m}$ \\
$27.75-45 \mu \mathrm{m}$ \\
$3 \times 400 \mu \mathrm{L}$ \\
\hline
\end{tabular}

Taken together, cell counter counted $1 / 42.5$ of pollen grains of one strobilus.

\section{Data analysis}

The distribution of pollen number and size data from a single strobilus were displayed using the CASY application (OMNI Life Science). A scatter plot was constructed using the R package ggplot2 [27].

Total pollen number per flower

$=$ Viable cell number counted by cell counter

$\times \frac{\text { Total suspension volume applied to cell counter }(10.2 \mathrm{ml})}{\text { Suspension volume counted by cell counter }(1.2 \mathrm{ml})}$

$\times \frac{\text { Total pollen suspension }(1 \mathrm{ml})}{\text { Pollen suspension mixed with CASYton }(0.2 \mathrm{ml})}$ 

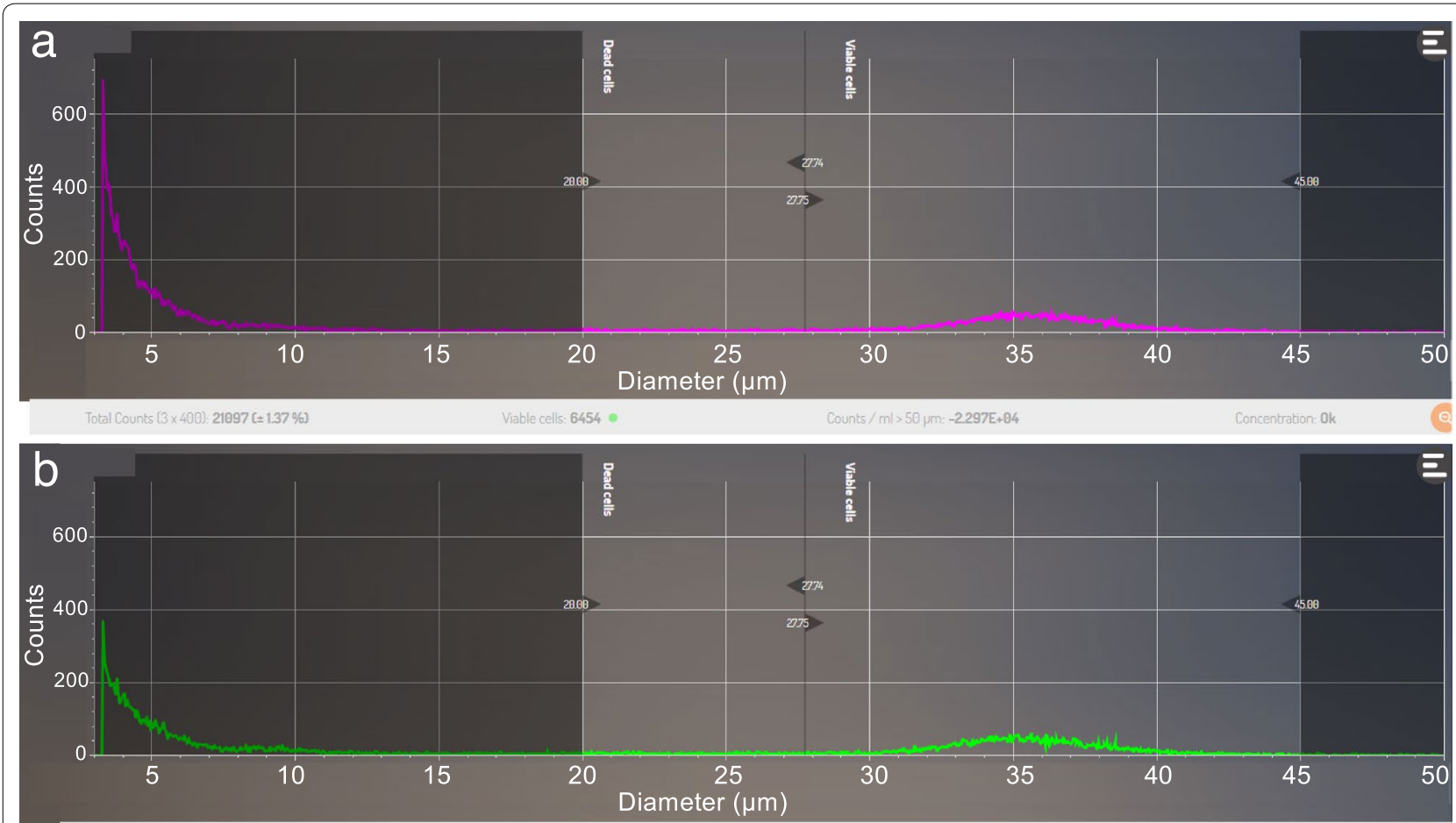

Total Counts $(3 \times 400): 17185(=2.53 \%)$

Viable cells: 6463

thounts $/ m \mathrm{ml}>50 \mathrm{um:}-2428 \mathrm{E}+04$
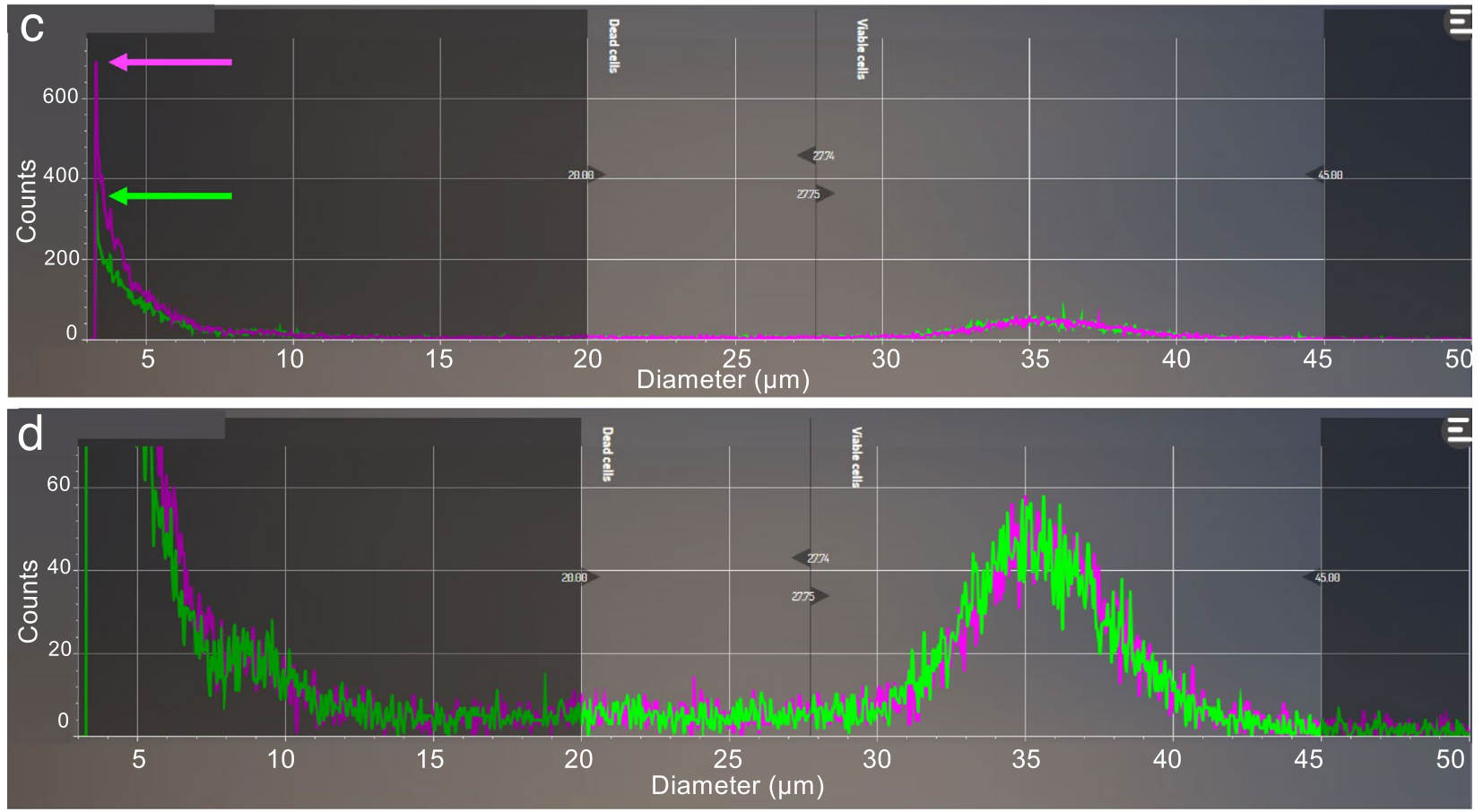

Fig. 4 Removal of small particles using a 20- $\mu$ m mesh column. Particle distributions from identical samples of I' wafune-15' clone were determined without ( $\mathbf{a}$ and $\mathbf{c}$; magenta) and with ( $\mathbf{b}$ and $\mathbf{c}$; green) passage through the 20- $\mu \mathrm{m}$ mesh column. Merged sample data are shown in $\mathbf{c}$ and $\mathbf{d}$. The $X$ axis indicates particle diameter $(\mu \mathrm{m})$ and the $Y$ axis indicates particle count. The limit of the $Y$ axis is 750 counts in a-c and 70 counts in $\mathbf{d}$. Peaks of the small debris section (0-20 $\mu \mathrm{m}$ ) are indicated by magenta (without 20- $\mu \mathrm{m}$ mesh column) and green (with 20- $\mu \mathrm{m}$ mesh column) arrows in c 
Table 2 Particle numbers with or without passage through the $20-\mu \mathrm{m}$ mesh column

\begin{tabular}{|c|c|c|c|c|c|c|c|c|c|c|}
\hline \multirow[t]{2}{*}{ Sample No. } & \multirow[t]{2}{*}{ Clone name } & \multicolumn{3}{|c|}{ Sample with $20 \mu \mathrm{m}$ mesh column } & \multicolumn{3}{|c|}{$\begin{array}{l}\text { Sample without } 20 \mu \mathrm{m} \text { mesh } \\
\text { column }\end{array}$} & \multicolumn{3}{|c|}{ With/without $20 \mu \mathrm{m}$ mesh column } \\
\hline & & Total counts & Viable cells & Debris & Total counts & Viable cells & Debris & $\begin{array}{l}\text { Reduced } \\
\text { debris } \\
\text { number }\end{array}$ & $\begin{array}{l}\text { Reduced } \\
\text { ratio (\%) }\end{array}$ & $\begin{array}{l}\text { Viable cell } \\
\text { ratio (\%) }\end{array}$ \\
\hline 1 & Iwa-9 & 15237 & 6094 & 9143 & 19072 & 6806 & 12266 & 3123 & 25.5 & 89.5 \\
\hline 2 & Iwa-15 & 17526 & 5797 & 11729 & 20266 & 6040 & 14226 & 2497 & 17.6 & 96.0 \\
\hline 3 & Iwa-15 & 16235 & 6222 & 10013 & 28594 & 6165 & 22429 & 12416 & 55.4 & 100.9 \\
\hline 4 & Iwa-15 & 17451 & 7633 & 9818 & 23346 & 6786 & 16560 & 6742 & 40.7 & 112.5 \\
\hline 5 & Iwa-15 & 17185 & 6463 & 10722 & 21097 & 6454 & 14643 & 3921 & 26.8 & 100.1 \\
\hline \multirow[t]{2}{*}{6} & Iwa-15 & 14232 & 6394 & 7838 & 17065 & 6433 & 10632 & 2794 & 26.3 & 99.4 \\
\hline & & & & & & & Average & 5249 & 32.0 & 99.7 \\
\hline
\end{tabular}

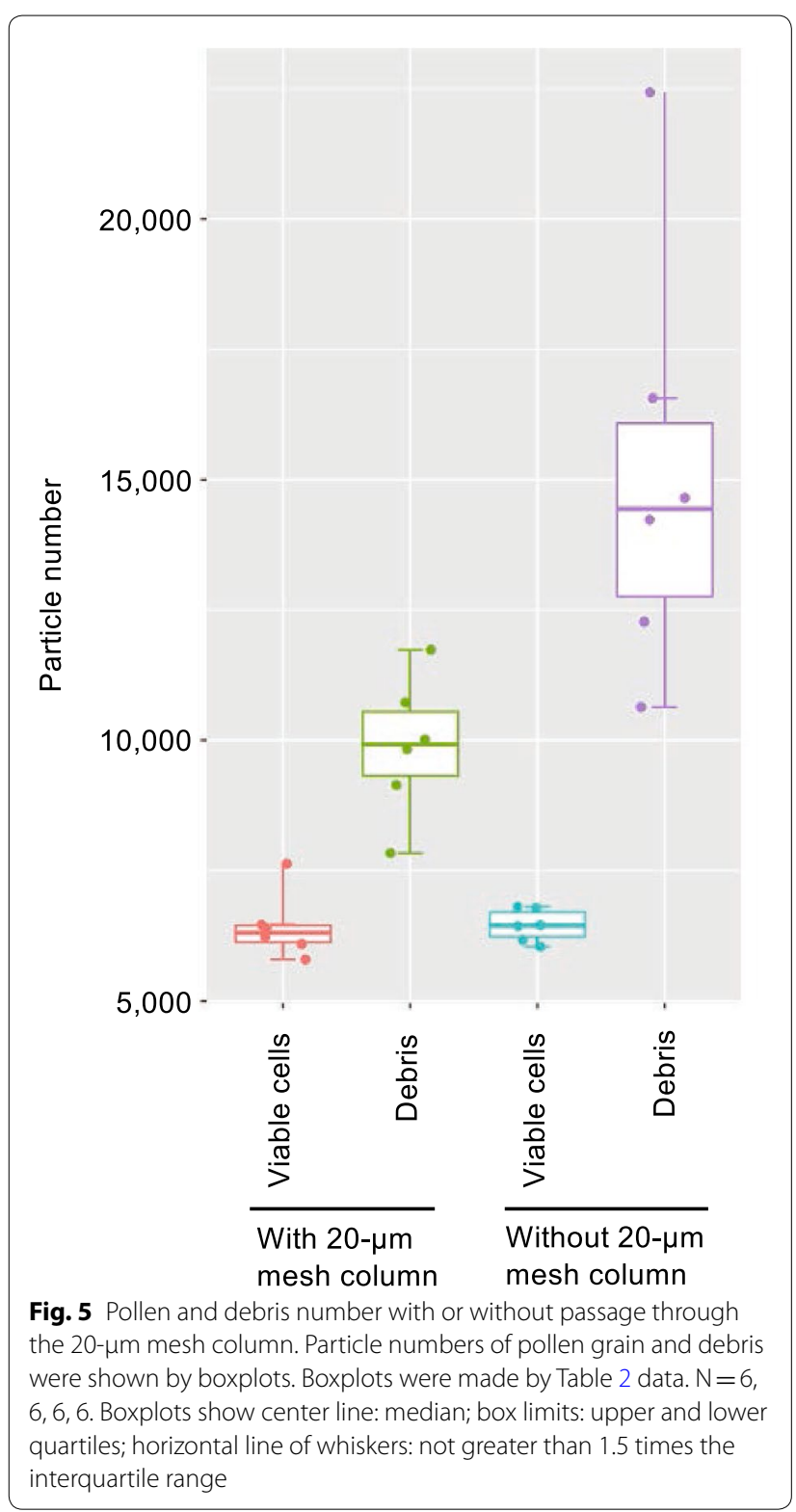

\section{Results}

Crushing the male strobilus using a pestle to collect pollen grains

To count the number of pollen grains per strobilus precisely, it is important to collect all of the pollen grains from the strobilus. The model plant $A$. thaliana has thin anthers that open easily at high temperatures $\left(60^{\circ} \mathrm{C}\right.$, overnight [15]). We attempted to open the male strobili of Japanese cedar by heating or drying, but this approach was not successful. The male strobilus of Japanese cedar has a hard scale structure, unlike the anthers from Arabidopsis species or wheat [15] (Fig. 3a). We then attempted to crush the male strobilus with a pestle to break the scale structure. Pollen grains are physically stronger than other plant tissues because they have an external wall layer called the exine, which is a physically and chemically resistant structure [28]. A male strobilus was gently crushed using a pestle (Fig. 3b, c), and then suspended in DW using a pipette (Fig. 3d). The scale structure was separated after pipetting and we successfully collected all of the pollen from the pollen-containing suspension (Fig. 3e, f).

\section{Removing large debris from the pollen-containing suspension using a $100-\mu \mathrm{m}$ mesh column}

The pollen suspension contained not only pollen grains but also large amounts of large and small debris (e.g., scale tissue, anther wall, etc.). Because the cell counter cannot count particles $>150 \mu \mathrm{m}$ due to the capillary becoming blocked, we made a $100-\mu \mathrm{m}$ mesh column to remove the large debris. Japanese cedar pollen typically has a round shape with a $35-\mu \mathrm{m}$ diameter as determined from microscope observations so it was unlikely to be retained by the $100-\mu \mathrm{m}$ mesh column. The pollen-containing suspension was loaded onto the $100-\mu \mathrm{m}$ mesh column and centrifuged. Large scale structures were retained in the column without stopping the 

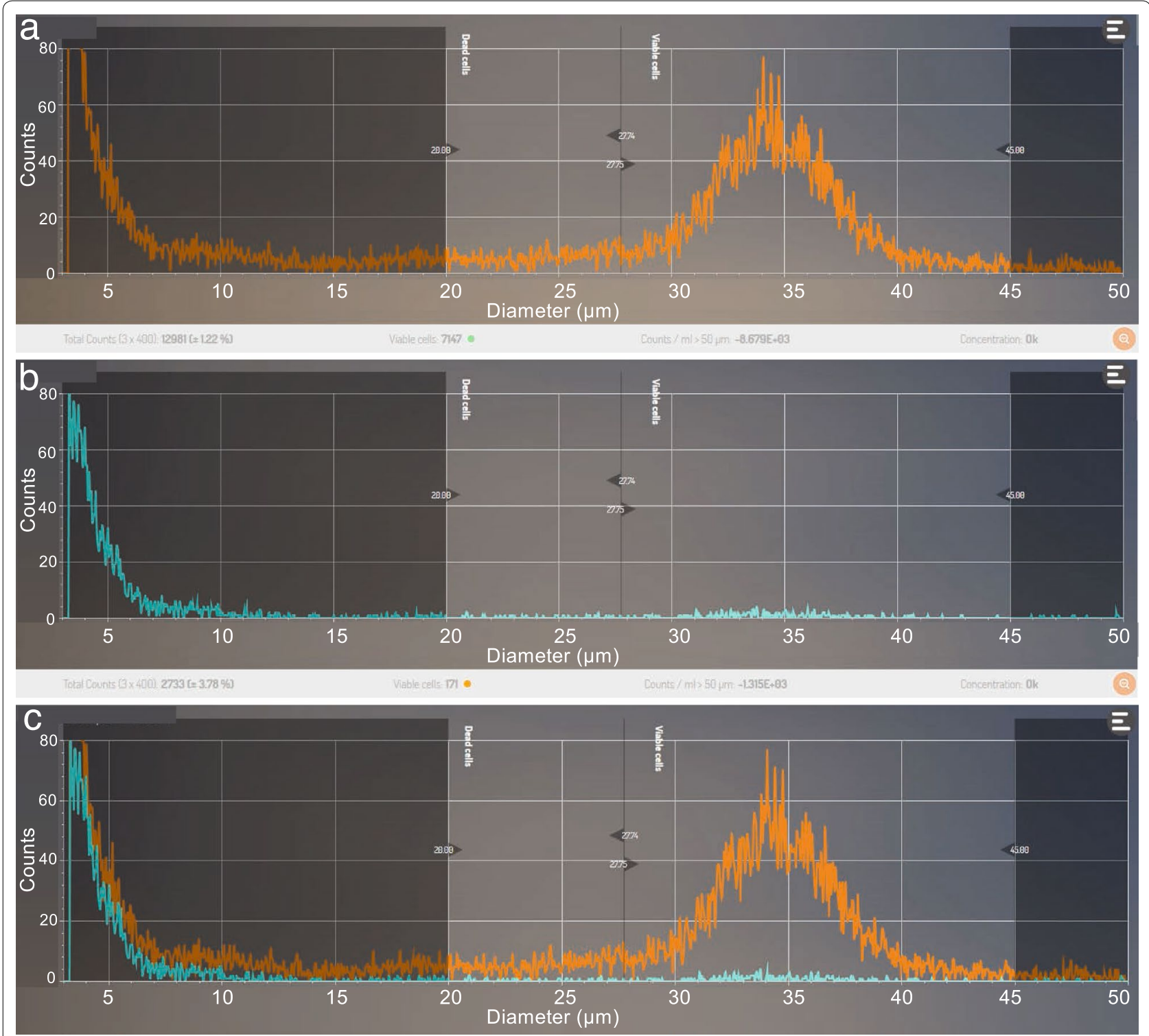

Fig. 6 Particle distribution from the flowthrough liquid after using the $20-\mu \mathrm{m}$ mesh column. Particle distributions in the pollen suspension (a) and flowthrough section (b) from 'Iwafune-15' clone. There was almost no detectable peak from the flowthrough section (b and $\mathbf{c}$ )

passage of the pollen grains. Pollen grains moved to the flowthrough area (Fig. 2d). The capillary of the cell counter remained unblocked throughout this study, suggesting that the $100-\mu \mathrm{m}$ mesh column successfully removed large debris.

\section{Removing small debris from the pollen-containing suspension using a $20-\mu \mathrm{m}$ mesh column}

The cell counter can count a maximum of 20,000 particles in a single measurement. The flowthrough suspension passing through the $100-\mu \mathrm{m}$ mesh column contained many small particles. Figure 4 shows the particle distribution with or without passage of the same sample through a 20- $\mu \mathrm{m}$ mesh column. More than 20,000 particles were detected in a pollen suspension without passage through a $20-\mu \mathrm{m}$ mesh column (total of 21,097 particles; Fig. 4a). In contrast, many small debris particles were removed after using the $20-\mu \mathrm{m}$ mesh column (total of 17,185 particles remained in suspension; Fig. 4b, c). In the 27.75 - to $45-\mu \mathrm{m}$ particle size range, almost the same number of pollen grains remained with or without the use of the $20-\mu \mathrm{m}$ mesh column (6454 vs 6463 particles, respectively; Fig. 4d). Table 2 and Fig. 5 shows the 
Table 3 Pollen numbers from 20- $\mu \mathrm{m}$ mesh columntrapped sample and flow through sample

\begin{tabular}{llll}
\hline Sample no. & \multicolumn{2}{l}{ Viable cells counts } & $\begin{array}{l}\text { Viable cell ratio } \\
\text { (\%) }\end{array}$ \\
\cline { 2 - 3 } & $\mathbf{2 0 \mu \text { m column }}$ & Flow through & $\begin{array}{l}\text { (Flow through/ } \\
\text { Total counts) }\end{array}$ \\
\hline 1 & 4597 & 133 & 2.81 \\
2 & 4563 & 121 & 2.58 \\
3 & 4381 & 118 & 2.62 \\
4 & 5378 & 130 & 2.36 \\
5 & 3826 & 44 & 1.14 \\
6 & 6233 & 179 & 2.79 \\
7 & 6578 & 171 & 2.53 \\
8 & 5446 & 154 & 2.75 \\
9 & 7421 & 193 & 2.53 \\
10 & 7147 & 171 & 2.34 \\
& & Average & 2.45 \\
\hline
\end{tabular}

efficiency of the 20- $\mu \mathrm{m}$ mesh column for removing small debris. Approximately, 32\% of the debris was removed using the $20-\mu \mathrm{m}$ mesh column. To check whether pollen grains leaked through the $20-\mu \mathrm{m}$ mesh column, the pollen number was counted for the pollen retained by the 20- $\mu \mathrm{m}$ mesh (normal pollen suspension) and for the pollen in the flowthrough after using the $20-\mu \mathrm{m}$ mesh column. The particle distribution pattern revealed a clear pollen peak from the pollen sample retained by the mesh, whereas there was no peak observed in the flowthrough (Fig. 6). Table 3 shows the numbers of particles between 27.75 and $45 \mu \mathrm{m}$ in the $20-\mu \mathrm{m}$ mesh column-trapped samples and flowthrough samples. Less than $3 \%$ of the particles were detected in flowthrough samples for all samples. These results suggest that the use of the 20- $\mu \mathrm{m}$ mesh column reduced the amount of small debris in the pollen suspension with no loss of pollen grains.

\section{Numbers and sizes of pollen grains from two Japanese cedar clones}

Pollen number and size for 'Iwafune-9' and 'Nishikanbara-1' were measured by the cell counter. Twenty-two strobili from 'Iwafune-9' and 30 strobili from 'Nishikanbara-1' were analyzed. Figure 7a shows the pollen number and size distribution of 52 samples. The two clones had clearly different pollen sizes. 'Iwafune-9' had a low pollen grain number (mean pollen number $=196,754$ ) but a larger pollen size (mean pollen diameter $=34.59 \mu \mathrm{m}$ ) compared to 'Nishikanbara-1' (mean pollen number $=304,429$, mean pollen diameter $=31.79 \mu \mathrm{m}$ ). Even among clones, there was more than a two-fold difference in pollen number. Such a large variation in pollen number from the same plant has also been reported in
Arabidopsis species and in wheat $[5,15]$. Figure $7 \mathrm{~b}$ shows the particle size distribution for representative samples from 'Iwafune-9' (magenta) and 'Nishikanbara-1' (green). Both samples showed a clear single peak in the viable cell range, which is the size range we expected based on microscopy observations. There was typically a $10-\mu \mathrm{m}$ variation in pollen size within the same strobilus (e.g., 30 to $40 \mu \mathrm{m}$ from 'Iwafune-9' and 26 to $37 \mu \mathrm{m}$ from 'Nishikanbara-1'; Fig. 7b).

\section{Detection of pollen cells released from exines using a cell counter}

Pollen of Japanese cedar has some unique features compared with angiosperm plant species. For example, mature Japanese cedar pollen cells include generative cells and tube cells [29]. When mature pollen attaches to the nucellus (pollination), the intine structure, including the pollen cell, is released from the exine structure and the germinated pollen tube grows through the nucellus [29]. This process is important for pollinosis patients because Cry j1 and Cry j2, which are the major allergenic proteins of Japanese cedar, are localized in the intine and intine is also released from the exine in the human eye [30-32]. In this study, most of the pollen grains were not released from exines after $24 \mathrm{~h}$ in DW (data not shown). On the other hand, we found that many pollen grains were released from the exine structure in CASYton after $30 \mathrm{~min}$ (Fig. 8a, b). The cell counter displayed an additional small peak after the pollen suspension was mixed with CASYton (Fig. 8c). The original pollen peak remained almost the same between 0 and $30 \mathrm{~min}$. Although the two peaks derived from the exine and pollen cells were indicated by different particle diameters, we recommend determining the pollen number immediately after mixing with CASYton for species which have similar traits because a small overlap of the two peaks was detected (Fig. $8 \mathrm{c}$, around $30 \mu \mathrm{m}$ diameter).

\section{Discussion}

Effectiveness of the improved pollen counting protocol with home-made mesh columns

We developed an improved protocol that allows pollen grains to be collected from a single strobilus without waiting for anthesis. We also demonstrated that two types of mesh could remove large and small debris efficiently. This system is a cost-effective method because the columns are home-made (one column costs less than 50 cents). In this method, the cell counter can count $1 / 42.5$ of pollen grains of single strobilus within $5 \mathrm{~min}$. This is much efficient and faster than the traditional microscope method because the standard microscope method only counts $1 / 10,000$ of pollen grains of single flower/strobilus 


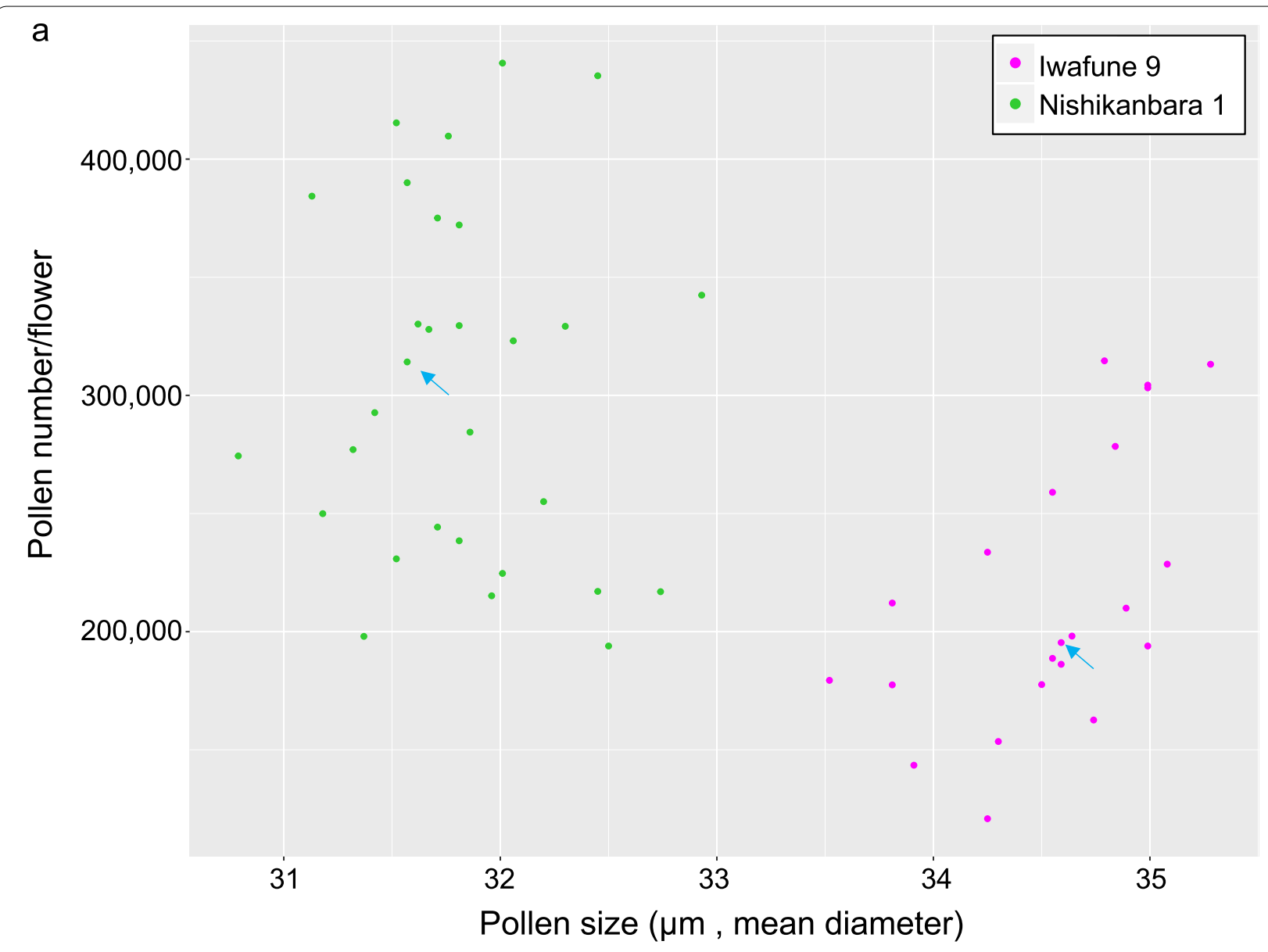

b

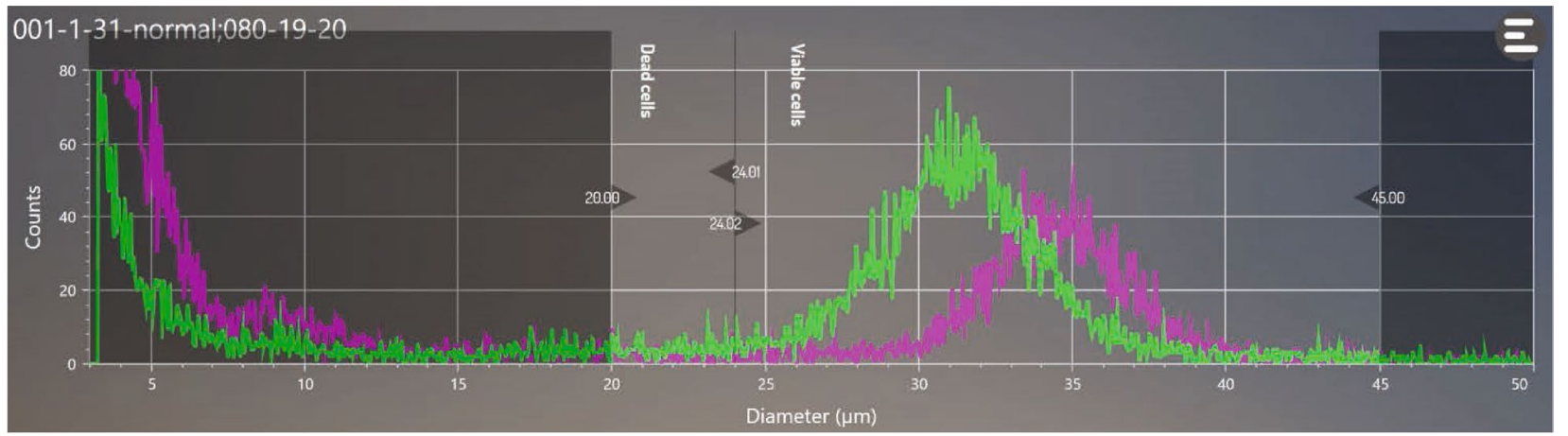

Fig. 7 Pollen numbers and size distributions from two Japanese cedar clones. a Scatter plots of 'Iwafune-9' (magenta) and 'Nishikanbara-1' (green) clones. Each dot indicates pollen number and size data from a single strobilus. Blue arrows indicate the representative samples of each clone displayed in $\mathbf{b}$. $\mathbf{b}$ Particle distributions from representative samples

\section{(See figure on next page.)}

Fig. 8 Artificial pollen release and detection by the cell counter. Microscope observations of pollen grains from 'Iwafune-9' clone in CASYton at $0 \mathrm{~min}(\mathbf{a})$ and $30 \mathrm{~min}$ (b). Eighteen of the 22 pollen grains had released the pollen cell from the exine structure after $30 \mathrm{~min}$. Bars $=50 \mu \mathrm{m}$. Arrow: released pollen cell, arrowhead: exine structure, asterisk: unreleased pollen. c Particle distributions at 0 min (magenta) and 30 min (green) for the same strobilus sample. Additional peaks derived from removed exine were observed in the sample after $30 \mathrm{~min}$ 

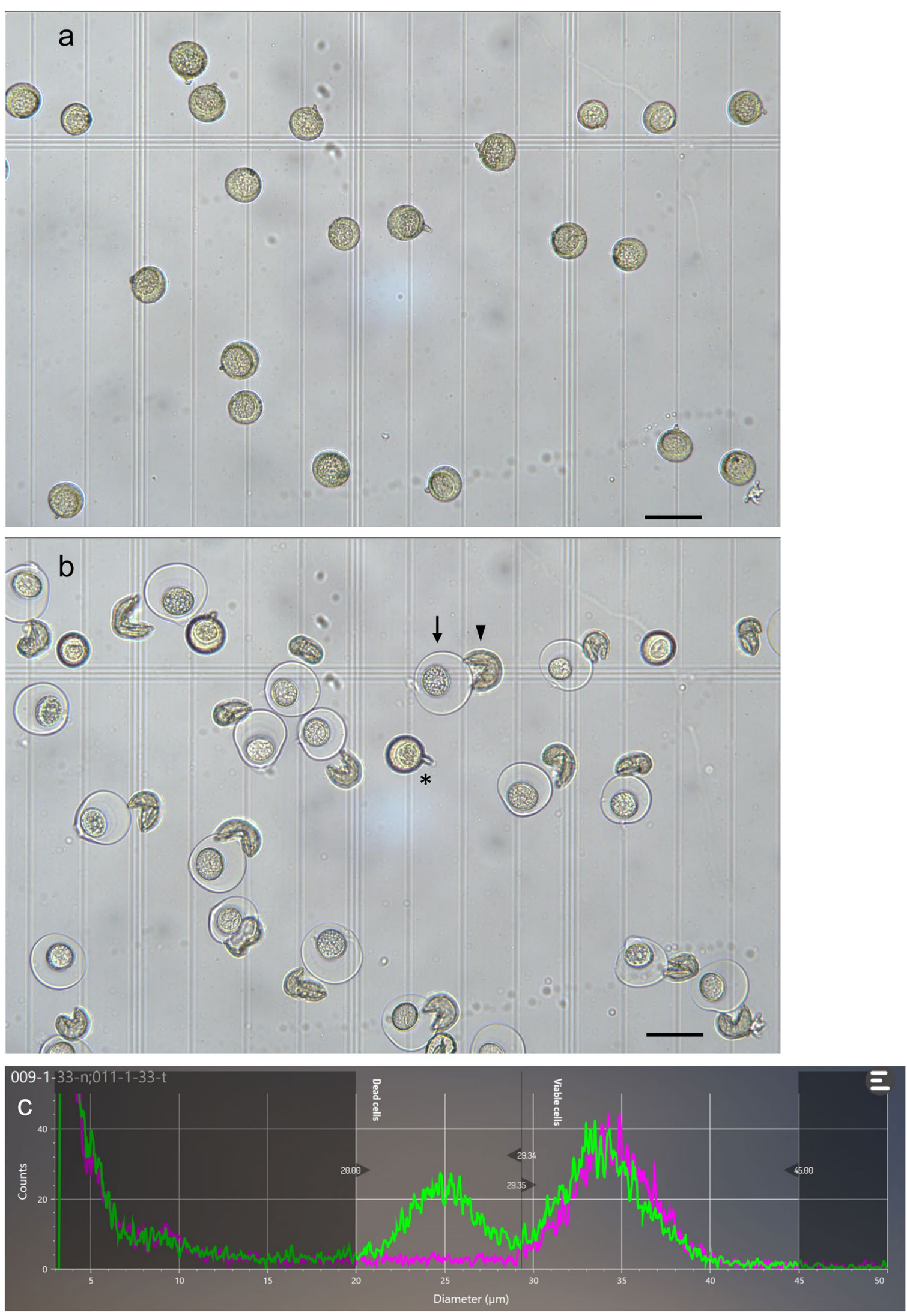
in $17 \mathrm{~min}$. [15]. Using this method, we can make lower pollen number clones by crossing low pollen number parents with superior woody traits. These offspring will have lower pollen numbers but have fine woody traits. For clonal propagation such as grafting, efficient pollen number counting will also contribute to choosing lower pollen number clones.

The cell counter revealed the pollen number and size variation between clones/samples and within samples in Japanese cedar. There was a 1.5 -fold difference in pollen number between the two clones. The clones were clearly distinguishable by pollen size. Broader pollen measurements using more clones will reveal trends in pollen number and size in Japanese cedar in the future.

This column method is applicable not only for Japanese cedar but is also possibly applicable to a broader range of species. For example, the strobili of Cupressaceae species, such as Cupressus, Juniperius, and Chamaecyparis species, typically have scale tissue similar to the Japanese cedar [33]. Counting the pollen grain number of these species is important because they are also pollinosis-causing species worldwide [16, 34, 35]. In plant breeding, an increase in pollen number is a desired trait [7]. Although we previously established a pollen counting method for wheat, elongation of anther filaments takes time and the method requires cutting both tips of the anther with a syringe to enhance pollen release [15]. The mesh column method described in this paper is less labor intensive and we are adopting this method to count wheat pollen now. In summary, this column method could possibly be applied to a broader range of species. The recent development of next-generation sequencing techniques allows unique genes to be identified in nonmodel species [36, 37]. Whole-genome sequencing is proceeding in Japanese cedar. The combination of our improved pollen counting method with a genome-wide analysis will provide new insights into pollen number, such as the identification of pollen number-controlling genes from Japanese cedar and wheat.

\section{Conclusions}

Herein, we report the efficient, high-throughput, and cost-effective pollen grain counting method applicable to flowers with hard scale tissue. This method is able to count 20,000 particles within $5 \mathrm{~min}$. It is more than 100 times than traditional hemocytometer method. Two types of home-made column work to remove large or small particles effectively at low cost. This method is not only applicable to Japanese cedar but also to a broad range of plant species.

\section{Acknowledgements}

We thank Yukiko Ito (Niigata prefectural forest research institute) for providing breeding materials, Junichi Nishimura (Nepa Gene) for technical assistance, Naoto-Benjamin Hamaya (University of Zurich) and Daisuke Kurihara (Nagoya University) for valuable suggestions.

\section{Authors' contributions}

HK and YM designed the research project. HK and ET performed the experiments. HS gave critical experimental idea. HK and ET analyzed data. HK wrote the manuscript. YM, HS, and ET modified the manuscript. All authors read and approved the final manuscript.

\section{Funding}

This work was supported by Japan Society for the Promotion of Science KAKENHI Grant Number 19 K05976 to HK, Project of the NARO Bio-oriented Technology Research Advancement Institution (Research program on development of innovative technology) Grant Number 28013BC to YM.

\section{Availability of data and materials}

The datasets used and/or analysed during the current study are available from the corresponding author on reasonable request.

Ethics approval and consent to participate

Not applicable.

Consent for publication

Not applicable.

\section{Competing interests}

The authors declare that they have no competing interests.

\section{Author details}

${ }^{1}$ Graduate School of Science and Technology, Niigata University, Niigata, Niigata 950-2181, Japan. ${ }^{2}$ Faculty of Agriculture, Niigata University, Niigata, Niigata 950-2181, Japan. ${ }^{3}$ Graduate School of Horticulture, Chiba University, Matsudo, Chiba 271-8510, Japan.

Received: 16 July 2020 Accepted: 8 September 2020

Published online: 14 September 2020

\section{References}

1. Darwin C. The different forms of flowers on plants of the same species. London: John Murray; 1877. https://doi.org/10.1017/CBO9780511731419

2. Cruden RW. Pollen-ovule ratios: a conservative indicator of breeding systems in flowering plants. Evolution. 1977;31:32-46.

3. Sicard A, Stacey N, Hermann K, Dessoly J, Neuffer B, Baeurle I, et al. Genetics, evolution, and adaptive significance of the selfing syndrome in the genus Capsella. Plant Cell. 2011;23:3156-71.

4. Shimizu KK, Tsuchimatsu T. Evolution of selfing: recurrent patterns in molecular adaptation. Annu Rev Ecol Evol Syst. 2015;46:593-622.

5. Tsuchimatsu T, Kakui H, Yamazaki M, Marona C, Tsutsui H, Hedhly A, et al. Adaptive reduction of male gamete number in the selfing plant Arabidopsis thaliana. Nat Commun. 2020;1 1:1-9.

6. Oka H-I, Morishima H. Variations in the breeding systems of a wild rice, Oryza perennis. Evolution. 1967:21:249-58.

7. Langer SM, Longin CFH, Würschum T. Phenotypic evaluation of floral and flowering traits with relevance for hybrid breeding in wheat (Triticum aestivum L.). Plant Breed. 2014;133:433-41.

8. Franco-Mora O, Tanabe K, Tamura F, Itai A. Effects of putrescine application on fruit set in "Housui" Japanese pear (Pyrus pyrifolia Nakai). Sci Hortic 2005; 104:265-73.

9. Gonzalez MV, Coque M, Herrero M. Influence of pollination systems on fruit set and fruit quality in kiwifruit (Actinidia deliciosa). Ann Appl Biol. 1998;132:349-55

10. Oh J-W. Pollen allergy in a changing world: a guide to scientific understanding and clinical practice. Singapore: Springer; 2018. 
11. D'Amato G, Cecchi L, Bonini S, Nunes C, Annesi-Maesano I, Behrendt $\mathrm{H}$, et al. Allergenic pollen and pollen allergy in Europe. Allergy. 2007:62:976-90.

12. Kersey PJ. Plant genome sequences: past, present, future. Curr Opin Plant Biol. 2019;48:1-8.

13. Stevens KA, Wegrzyn JL, Zimin A, Puiu D, Crepeau M, Cardeno C, et al. Sequence of the sugar pine megagenome. Genetics. 2016;204:1613-26.

14. IWGSC. Shifting the limits in wheat research and breeding using a fully annotated reference genome. Science. 2018:361:eaar7191.

15. Kakui H, Yamazaki M, Hamaya N-B, Shimizu KK. Pollen grain counting using a cell counter. In: Geitmann A, editor. Pollen and Pollen Tube Methods. Methods in Molecular Biology. Humana Press; 2020;2160: 1-11.

16. Charpin D, Calleja M, Lahoz C, Pichot C, Waisel Y. Allergy to cypress pollen. Allergy. 2005;60:293-301.

17. Tsumura Y. Cryptomeria. In: Kole C, editor. Wild crop relatives: genomics and breeding resources, forest trees. Berlin: Springer; 2011. p. 49-64

18. Kondo T, Senda M. Tabuchi K Pollen grain number in a male flower of Sugi (Cryptomeria japonica). J Jpn Forest Soc. 1992;103:329-30 (in Japanese)

19. Ikuse M. On the number of pollen grains contained in anthers of some plants. Quaternary Res. 1965;4:3-4 (in Japanese)

20. Willis $\mathrm{JH}$. The contribution of male-sterility mutations to inbreeding depression in Mimulus guttatus. Heredity. 1999;83:337-46.

21. De Vries AP. Some aspects of cross-pollination in wheat (Triticum aestivum L.). 3. Anther length and number of pollen grains per anther. Euphytica. 1974;23:11-9.

22. Ortega R, Aresti M, Pereira I. Implementation and evaluation of an image analysis system for determining viability of pollen grains in temperate rice. Chil J Agric Res. 2011;71:16-22.

23. Heidmann I, Schade-Kampmann G, Lambalk J, Ottiger M, Di Berardino M. Impedance flow cytometry: a novel technique in pollen analysis. PLoS ONE. 2016;11:e0165531.

24. Heidmann I, Di Berardino M. Impedance flow cytometry as a tool to analyze microspore and pollen quality. In: Schmidt A. editor, Plant Germline Development. Methods in Molecular Biology. Humana Press; 2017;1669: 339-54.

25. Tsubomura M, Kurita M, Watanabe A. Determination of male strobilus developmental stages by cytological and gene expression analyses in Japanese cedar (Cryptomeria japonica). Tree Physiol. 2016;36:653-66.
26. Akaogi K and Miyazaki K. Protein purification by SDS-PAGE. In: Okada M, Miyazaki K, editors. Notebook for Protein Experiments (3rd edition). Yodosha Japan. 2011. p.31-32. (in Japanese).

27. Wickham H. ggplot2: elegant graphics for data analysis (Use R). 2009. https://doi.org/10.1007/978-0-387-98141-3.

28. Ariizumi T, Toriyama K. Genetic regulation of sporopollenin synthesis and pollen exine development. Annu Rev Plant Biol. 2011:62:437-60.

29. Hiratsuka R, Terasaka O. Role of pectinase Cryj 2 during pollen tube growth in Cryptomeria japonica. Jpn J Palynol. 2012;58:51-9 (in Japanese)

30. Taniguchi Y, Ono A, Sawatani M, Nanba M, Kohno K, Usui H, et al. Cry jl, a major allergen of Japanese Cedar pollen, has pectate lyase enzymeactivity. Allergy. 1995;50:90-3.

31. Ohtsuki T, Taniguchi Y, Kohno K, Fukuda S, Usui M, Kurimoto M. Cryj 2, a major allergen of Japanese Cedar Pollen, shows polymethylgalacturonase activity. Allergy. 1995:50:483-8.

32. Miki-Hirosige H, Nakamura S, Yasueda H, Shida T, Takahashi Y. Immunocytochemical localization of the allergenic proteins in the pollen of Cryptomeria japonica. Sex Plant Reprod. 1994;7:95-100.

33. Schulz C, Klaus KV, Knopf P, Mundry M, Dörken VM, Stützel T. Male cone evolution in conifers: not all that simple. Am J Plant Sci. 2014;5:2842-57.

34. Van de Water PK, Keever T, Main CE, Levetin E. An assessment of predictive forecasting of Juniperus ashei pollen movement in the Southern Great Plains, USA. Int J Biometeorol. 2003;48:74-82.

35. Hrabina M, Dumur JP, Sicard H, Viatte A, Andre C. Diagnosis of cypress pollen allergy: in vivo and in vitro standardization of a Juniperus ashei pollen extract. Allergy. 2003;58:808-13.

36. Akagi T, Henry IM, Tao R, Comai L. A Y-chromosome-encoded small RNA acts as a sex determinant in persimmons. Science. 2014;346:646-50.

37. Akagi T, Pilkington SM, Varkonyi-Gasic E, Henry IM, Sugano SS, Sonoda M, et al. Two Y-chromosome-encoded genes determine sex in kiwifruit. Nat Plants. 2019;5:801-9.

\section{Publisher's Note}

Springer Nature remains neutral with regard to jurisdictional claims in published maps and institutional affiliations.
Ready to submit your research? Choose BMC and benefit from:

- fast, convenient online submission

- thorough peer review by experienced researchers in your field

- rapid publication on acceptance

- support for research data, including large and complex data types

- gold Open Access which fosters wider collaboration and increased citations

- maximum visibility for your research: over 100M website views per year

At BMC, research is always in progress.

Learn more biomedcentral.com/submissions 